\title{
PENGARUH MODEL PEMBELAJARAN TWO STAY TWO STRAY TERHADAP HASIL BELAJAR IPA
}

\author{
Ni Kd. Depi Dumaini \\ Program Studii Pendidikan Guru Sekolah Dasar, Universitas Pendidikan Ganesha \\ depidumaini@yahoo.com \\ I Made Suarjana \\ Program Studii Pendidikan Guru Sekolah Dasar, Universitas Pendidikan Ganesha \\ suarjana_undiksha@yahoo.co.id \\ I Ketut Dibia \\ Program Studii Pendidikan Guru Sekolah Dasar, Universitas Pendidikan Ganesha \\ dibiaketut@yahoo.com
}

\begin{abstract}
Abstrak
Penelitian ini bertujuan untuk mengetahui pengaruh yang signifikan hasil belajar IPA antara kelompok siswa yang dibelajarkan dengan model pembelajaran kooperatif tipe two stay two stray dan kelompok siswa yang dibelajarkan dengan model pembelajaran konvensional pada siswa kelas V SD Semester II di Gugus IV Kecamatan Abang Kabupaten Karangasem Tahun Pelajaran 2017/2018. Jenis penelitian ini adalah penelitian eksperimen semu dengan rancangan nonequivalent posttest only control group design. Populasi penelitian ini adalah seluruh siswa kelas V SD di Gugus IV Kecamatan Abang Kabupaten Karangasem yang berjumlah 121 orang. Sampel penelitian yaitu siswa kelas V SDN 2 Culik dan siswa kelas V SDN 3 Culik. Data hasil belajar IPA dikumpulkan menggunakan tes objektif pilihan ganda. Data yang diperoleh dianalisis dengan menggunakan statistik deskriptif dan statistik inferensial. Hasil penelitian menunjukkan terdapat pengaruh yang signifikan hasil belajar IPA antara kelompok siswa yang dibelajarkan dengan model pembelajaran kooperatif tipe two stay two stray dan kelompok siswa yang dibelajarkan dengan model pembelajaran konvensional. Hal ini diketahui dari hasil analisis hipotesis dengan uji-t, $t_{\text {hitung }}$ lebih besar dibandingkan dengan $t_{\text {tabel }}\left(t_{\text {hitung }} 6,08>t_{\text {tabel }} 2,021\right)$, dengan perhitungan rata-rata skor hasil belajar IPA kelompok eksperimen adalah 24,11 lebih besar dari rata-rata skor hasil belajar IPA kelompok kontrol yaitu 17,23. Dengan demikian, dapat disimpulkan bahwa model pembelajaran kooperatif tipe two stay two stray berpengaruh terhadap hasil belajar IPA siswa kelas V SD Semester II di Gugus IV Kecamatan Abang Kabupaten Karangasem Tahun Pelajaran 2017/2018.
\end{abstract}

Kata kunci: model two stay two stray, hasil belajar, IPA, gugus IV

\begin{abstract}
This study aims to determine the significant influence of science learning outcomes between groups of students who were taught by cooperative learning model type two stay two stray and group of students who were taught by conventional learning model in V grade students of SD Semester II in Gugus IV Abang District Karangasem Regency Lesson Year 2017/2018. This research type is quasi experiment research with non-equivalent design posttest only control group design. The population of this research is all students of class V SD in Gugus IV Abang Sub-district Karangasem Regency which amounted to 121 people. The sample of the research are students of class V SDN 2 Culik and students of grade V SDN 3 Culik. Science learning outcomes were collected using multiple-choice objective tests. The data obtained were analyzed using descriptive statistics and inferential statistics. The results showed that there were significant influence of science learning outcomes between groups of students who were taught by cooperative learning model type two stay two stray and group of students who were taught by conventional learning model. It is known from result of hypothesis analysis with t-test, tcount bigger than ttable (tcount 6,08> ttable 2,021), with calculation of average score of experiment result of science experiment group is 24,11 bigger than the average score of control group learning outcomes is 17.23 . Thus, it can be concluded that the cooperative learning model type two stay two stray effect on the learning outcomes of science V grade students of SD semester II in Gugus IV Abang District Karangasem regency year 2017/2018.
\end{abstract}

Key words: model two stay two stray, learning outcomes, science, gugus IV 


\section{Pendahuluan}

Ilmu Pengetahuan Alam (IPA) merupakan ilmu pengetahuan yang sangat erat kaitannya dengan kehidupan sehari-hari. Dalam pelajaran IPA siswa akan akan lebih mengenal lingkungannya secara langsung. Dalam kehidupan sehari-hari, IPA diperlukan untuk memenuhi kebutuhan manusia melalui pemecahan masalahmasalah yang dapat diidentifikasikan. Putri (2017:3) menyatakan, "pada prinsipnya, pembelajaran muatan materi IPA menekankan pada pemberian pengalaman belajar secara langsung untuk dapat mengembangkan pemahaman siswa mengenai alam sekitarnya dan dapat mengaplikasikan ke dalam kehidupan sehari-hari”. Badan Nasional Standar Pendidikan (dalam Susanto, 2013:171) menyatakan "tujuan pembelajaran sains di sekolah dasar, dimaksudkan untuk: (1) Memperoleh keyakinan terhadap kebesaran Tuhan Yang Maha Esa berdasarkan keberadaan, keindahan, dan keteraturan alam ciptaan-Nya, 2) Mengembangkan pengetahuan dan pemahaman konsep-konsep IPA yang bermanfaat dan dapat diterapkan dalam kehidupan sehari-hari; (3) Mengembangkan rasa ingin tahu, sikap positif dan kesadaran tentang adanya hubungan yang saling mempengaruhi antara IPA, lingkungan, teknologi, dan masyarakat; (4) Mengembangkan keterampilan proses untuk menyelidiki alam sekitar, memecahkan masalah dan membuat keputusan; (5) Meningkatkan kesadaran untuk berperan serta dalam memelihara, menjaga, dan melestarikan lingkungan alam; (6) Meningkatkan kesadaran untuk menghargai alam dan segala keteraturannya sebagai salah satu ciptaan Tuhan; (7) Memperoleh bekal pengetahuan, konsep, dan keterampilan IPA sebagai dasar untuk melanjutkan pendidikan ke SMP.

Sesuai dengan Badan Nasional Standar Pendidikan, dapat diketahui bahwa Ilmu Pengetahuan Alam sangat bermanfaat sehingga dapat diterapkan dalam kehidupan sehari-hari. Dengan belajar Ilmu Pengetahuan Alam (IPA) siswa dapat melatih potensinya dalam berfikir kritis, serta dapat mengembangkan rasa ingin tahu siswa. IPA mengajarkan untuk selalu menghargai alam dan sekitarnya. Pembelajaran IPA bertujuan membantu agar siswa memahami konsep IPA dan keterkaitannya dengan kehidupan sehari-hari. IPA merupakan mata pelajaran yang sangat penting bagi siswa SD, karena IPA di SD merupakan cikal bakal perkembangan IPA pada mata pelajaran yang akan didapatkan pada jenjang pendidikan selanjutnya.

Karlina (2017:2) menyatakan, "kegiatan pembelajaran IPA di sekolah saat ini cenderung membosankan, karena guru lebih menekankan pada penghafalan materi. Ini berarti bahwa peserta didik hanya menerima materi yang diberikan oleh guru dan aktifitas di kelas didominasi oleh guru". Hal tersebut menyebabkan siswa merasa jenuh dengan pembelajaran yang monoton tanpa ada variasi yang akan membangkitkan semangat dan motivasi siswa. Kebanyakan guru kurang memberikan fasilitas untuk siswa agar dapat mengkonstruksi dan mengeksplorasi kemampuannya sendiri. Siswa kurang dilibatkan sepenuhnya dalam pembelajaran dan tidak dilatih untuk menggali kemampuannya, mengolah informasi, mengambil keputusan secara tepat, dan memecahkan masalah. Siswa hanya sebagai penerima informasi dan guru hanya sebagai perantara materi dalam proses pembelajaran sehingga pembelajaran menjadi kurang bermakna bagi siswa.

Putri (2017:3) meyatakan, "pada kenyataannya mata pelajaran IPA masih dianggap sebagai salah satu mata pelajaran yang cukup sulit bagi siswa dari tingkat Sekolah Dasar (SD) sampai tingkat sekolah menengah". Hal ini karena guru hanya memberikan hafalan bukan mengajak siswa untuk menemukan suatu konsep untuk dipahami. Siswa yang dapat menemukan sendiri konsep pengetahuannya, akan lebih mudah dan lebih lama mengingat konsep pengetahuan yang diajarkan. Sedangkan siswa yang hanya menghafal materi dan konsep yang sudah ada cenderung lebih cepat lupa terhadap materi yang diajarakan, siswa yang hanya menghafal materi bisa jadi tidak mengerti dengan materi yang diajarkan, karena ia hanya terfokus untuk mengahfal tanpa memahami. Siswa yang cenderung mengahafal informasi akan akan lebih cepat jenuh/bosan, kurang termotivasi dan tidak semangat untuk belajar, sehingga menyebabkan proses pembelajaran menjadi tidak efektif. Hal tersebut akan menimbulkan dampak yang negatif bagi siswa yaitu tidak tercapainya tujuan pembelajaran secara maksimal.

Hasil pencatatan dokumen yang dilakukan pada tanggal 15 dan 16 Desember 2017 di seluruh SD Gugus IV Kecamatan Abang Kabupaten Karangasem diperoleh, nilai rata-rata UAS IPA Siswa Kelas V SD yang mencapai KKM sebesar 34,71 dan rata-rata hasil belajar siswa kelas V yang belum mencapai KKM sebesar 65,29. Hal tersebut menunjukan hasil belajar IPA siswa kelas V SD di Gugus IV Kecamatan Abang Kabupaten Karangasem tahun pelajaran 2017/2018 masih tergolong rendah.

Observasi yang dilakukan di masing-masing SD di Gugus IV Kecamatan Abang diperoleh hasil, tidak tercapainya tujuan pembelajaran secara maksimal khususnya hasil belajar IPA dipengaruhi oleh beberapa faktor yaitu: (1) model pembelajaran di SD yang lebih banyak menerapkan metode ceramah dan berpusat pada guru; (2) siswa hanya dijadikan objek pembelajaran oleh guru; (3) siswa kurang berpartisipasi secara aktif dalam pembelajaran; (4) pembelajaran bersifat hafalan semata sehingga kurang bergairah dalam belajar; (5) dalam proses pembelajaran proses interaksi searah hanya dari guru ke siswa; (6) kurangnya pemanfaatan lingkungan sekitar sebagai sumber belajar yang baik bagi siswa; dan (7) kurangnya kemampuan guru untuk memilih model pembelajaran yang sesuai dengan karakteristik dan kebutuhan belajar siswa.

Hasil pencatatan dokumen dan observasi ditemukan berbagai permasalahan dalam proses pembelajaran IPA dikelas, untuk itu guru harus kreatif dan inovatif dalam merancang model pembelajaran yang memungkinkan siswa dapat berpartisipasi aktif dalam proses pembelajaran. Salah satu model pembelajaran yang dapat digunakan adalah model pembelajaran kooperatif tipe two stay two stray (dua tinggal dua tamu tinggal). 
Lie (2002:61) menyatakan, "struktur dua tinggal dua tamu memberikan kesempatan kepada kelompok untuk membagikan hasil dan informasi dengan kelompok lain". Pratiwi (2016:4) menyatakan, "model pembelajaran ini berbeda dengan model kooperatif lainya, ciri TSTS adalah dua orang tetap dikelompoknya dan dua orang mencari informasi ke kelompok lainya". Model pembelajaran ini akan mengajak siswa untuk aktif dalam kelompoknya, belajar menyampaikan dan mengemukakan pendapatnya menggunakan bahasa yang mudah dipahami. Melalui pembelajaran dengan model pembelajaran kooperatif tipe two stay two stray ini kemampuan siswa diharapkan dapat dieksplorasi, siswa dapat aktif dalam pembelajaran, menjadi termotivasi untuk belajar sehingga hasil belajar siswa dapat ditingkatkan. Darmayasa (2013:3) menyatakan, "penggunaan model pembelajaran kooperatif tipe two stay two stray akan mengarahkan siswa untuk aktif, baik dalam berdiskusi, tanya jawab, mencari jawaban, menjelaskan dan menyimak materi yang dijelaskan oleh temannya".

Model pembelajaran kooperatif tipe two stay two stray ini akan melatih siswa agar dapat berpartisipasi aktif dalam pembelajaran secara merata sehingga mampu mengolah informasi yang sudah diperoleh dan berani mengemukakannya ke depan kelas. Jadi model pembelajaran ini dapat melibatkan siswa secara utuh, sehingga siswa dapat berekspresi, dan berinovasi atau yang sering disebut student centered. Model pembelajaran kooperatif tipe two stay two stray dilakukan di dalam kelas dengan suasana yang menyenangkan karena dalam pembelajarannya siswa dituntut untuk dapat mengungkapkan kembali informasi yang diperoleh secara benar sesuai dengan informasi yang diterimanya, pembelajaran yang menyenangkan ini dapat menciptakan suasana kelas yang kondusif sehingga semangat siswa untuk aktif dalam belajar juga semakin meningkat.

Tujuan penelitian ini adalah untuk mengetahui perbedaan yang signifikan hasil belajar IPA antara kelompok siswa yang dibelajarkan model pembelajaran kooperatif tipe two stay two stray dengan kelompok siswa yang dibelajarkan model pembelajaran konvensional pada siswa kelas V SD Semester II di Gugus IV Kecamatan Abang Kabupaten Karangasem Tahun Pelajaran 2017/2018. Berdasarkan uraian di atas, maka akan dilakukan penelitian eksperimen dengan menerapkan salah satu model pembelajaran kooperatif untuk mengetahui seberapa besar pengaruh model pembelajaran kooperatif tipe two stay two stray terhadap hasil belajar siswa, dengan judul "Pengaruh Model Pembelajaran Kooperatif Tipe Two Stay Two Stray Terhadap Hasil Belajar IPA Siswa Kelas V SD Semester II di Gugus IV Kecamatan Abang, Kabupaten Karangasem Tahun Pelajaran 2017/2018".

\section{Metode}

Penelitian ini dilakukan di SD Gugus IV Kecamatan Abang, Kabupaten Karangasem. Pelaksanaan penelitian ini pada semester II tahun pelajaran 2017/2018. Jenis penelitian yang dilakukan adalah eksperimen semu (quasi experiment). Penelitian ini menggunakan rancangan non-equivalent post-test only control group design.

Sugiyono (2011a:80) menyatakan, "populasi adalah wilayah generalisasi yang terdiri atas obyek/subyek yang mempunyai kualitas dan karakteristik tertentu yang ditetapkan oleh peneliti untuk dipelajari dan kemudian ditarik kesimpulannya". Populasi dalam penelitian ini adalah seluruh siswa kelas V SD di Gugus IV Kecamatan Abang berjumlah 121 orang. Pengambilan sampel menggunakan teknik random sampling. Sebelum menentukan sampel penelitian, dilakukan uji kesetaraan terhadap populasi penelitian. Untuk menghitung kesetaraan populasi digunakan analisis varian satu jalur (Anava A). Hasil uji kesetaraan diperoleh hasil, seluruh siswa memiliki kemampuan yang setara. Selanjutnya, kelas-kelas tersebut dirandom untuk menentukan sampel penelitian kedua kelompok sampel. Dalam proses undian tersebut ditetapkan SD Negeri 2 Culik terpilih sebagai kelompok eksperimen yang diberikan perlakuan dengan menggunakan model pembelajaran kooperatif tipe two stay two stray dan SD Negeri 3 Culik sebagai kelompok kontrol dengan menggunakan model pembelajaran konvensional.

Penelitian ini melibatkan dua variabel, yakni variabel bebas dan variabel terikat. Variabel bebas (independent variabel) dalam penelitian ini yaitu model pembelajaran kooperatif tipe two stay two stray yang diterapkan pada kelompok eksperimen dan model pembelajaran konvensional yang diterapkan pada kelompok kontrol. Variabel terikat (dependent variabel) dalam penelitian ini adalah hasil belajar IPA.

Metode pengumpulan data yang digunakan adalah metode tes. Instrumen pengumpulan data yang digunakan adalah tes hasil belajar IPA. Fernanades (dalam Koyan, 2011:15) menyatakan, "tes adalah suatu prosedur yang sistematis untuk mengamati perilaku seorang dan menggambarkannya dengan bantuan skala numerik atau sistem kategori tertentu". Dalam penelitian ini hanya digunakan tes objektif dalam bentuk pilihan ganda.

Sebelum melakukan uji coba instrumen, dilakukan uji judges terhadap instrumen hasil belajar IPA. Selanjutnya, dilakukan uji coba instrumen. Data yang diperoleh dari uji coba instrumen dianalisis dengan menggunakan uji validitas, uji reliabilitas tes, indeks daya beda, dan taraf kesukaran tes. Analisis dilakukan dengan menggunakan program komputer Microsoft Office Excel 2007.

Uji coba instrumen dilakukan terhadap siswa kelas VI di dua SD Gugus IV Kecamatan Abang yaitu kelas VI SD Negeri 2 Culik dan kelas VI SD Negeri 1 Labasari. Jumlah responden keseluruhan adalah 50 orang siswa. Hasil uji validitas diperoleh hasil 35 butir soal valid dan 5 butir soal gugur dari 40 soal yang diuji 
cobakan. Hasil uji reliabilitas tes diperoleh sebesar 0,84 termasuk dalam kriteria reliabilitas sangat tinggi. Hasil uji taraf kesukaran, diperoleh hasil 33 butir soal berada pada kriteria sedang dan 7 butir soal berada pada kriteria mudah. Taraf kesukaran perangkat tes berada pada kriteria sedang. Hasil uji daya beda, diperoleh 5 butir soal berada pada kriteria kurang baik, 9 butir soal berada pada kriteria cukup baik, 19 butir soal berada pada kriteria baik dan 7 butir soal berada pada kriteria sangat baik. Daya beda perangkat tes berada pada kriteria baik.

Analisis data yang digunakan yaitu analisis statistik deskriptif dan analisis statistik inferensial. Analisis inferensial meliputi uji prasyarat analisis dan uji hipotesis. Sebelum melaksanakan uji hipotesis dilakukan uji prasyarat. Uji prasyarat yang dilakukan adalah uji normalitas sebaran data dengan analisis chi-square dan uji homogenitas varians dengan menggunakan uji-F. Untuk menguji hipotesis digunakan uji-t sampel independent.

\section{Hasil dan Pembahasan}

Hasil analisis data hasil belajar IPA kelompok eksperimen dan kelompok kontrol disajikan dalam Tabel 1.

Tabel 1. Deskripsi Data Hasil Belajar IPA

\begin{tabular}{lcc}
\hline \multicolumn{1}{c}{ Statistik } & Kelompok Eksperimen & Kelompok Kontrol \\
\hline Skor maksimum & 30 & 26 \\
Skor minimum & 16 & 12 \\
Rentangan & 15 & 15 \\
Mean & 24,11 & 17,23 \\
Median & 25,14 & 16,81 \\
Modus & 26,36 & 16,36 \\
Varians & 16,54 & 10,28 \\
Standar Deviasi & 4,07 & 3,21
\end{tabular}

Berdasarkan Tabel 1, terlihat bahwa skor rata-rata (M) hasil belajar IPA siswa kelompok eksperimen yang dibelajarkan dengan model pembelajaran kooperatif tipe two stay-two stray lebih besar daripada rata-rata skor hasil belajar IPA siswa kelompok kontrol yang dibelajarkan dengan model pembelajaran konvensional.

Untuk mengetahui tinggi rendahnya kualitas dari variabel hasil belajar IPA kelompok eksperimen dan kelompok kontrol, skor rata-rata hasil belajar IPA siswa dikonversikan ke dalam Penilaian Acuan Patokan (PAP) skala lima. Hasil analisis data diperoleh, skor rata-rata hasil belajar kelompok eksperimen adalah 24,11, jika dikonversikan ke dalam PAP skala lima berada pada kategori sangat tinggi. Skor rata-rata hasil belajar kelompok kontrol adalah 17,23, jika dikonversikan ke dalam PAP skala lima berada pada kategori sedang.

Sebelum melakukan uji hipotesis, dilakukan uji prasyarat yang meliputi uji normalitas sebaran data dan uji homogenitas varian. Uji normalitas sebaran data dilakukan untuk mengetahui apakah sebaran data skor hasil belajar siswa pada masing-masing kelas berdistribusi normal atau tidak. Uji normalitas data dilakukan terhadap skor hasil belajar IPA siswa, baik kelompok eksperimen maupun kelompok kontrol. Kriteria pengujian jika, $\chi_{\text {hitung }}^{2} \chi^{2}$ tabel dengan taraf signifikasi $5 \%(\mathrm{dk}=$ jumlah kelas interval - parameter -1$)$, maka data dinyatakan berdistribusi normal, jika $\chi^{2}$ hitung $>\chi^{2}$ tabel maka data dinyatakan berdistribusi tidak normal. Hasil perhitungan dengan menggunakan rumus Chi-Square $\left(\chi^{2}\right)$, diperoleh $\chi^{2}$ hitung hasil post-test kelompok eksperimen sebesar 3,94 dan $\chi^{2}$ tabel dengan taraf signifikansi 5\% dan derajat kebebasan (dk) $=2$ adalah 5,59. Hal ini berarti, $\chi^{2}$ hitung hasil post-test kelompok eksperimen lebih kecil dari $\chi^{2}$ tabel $(3,94<5,59)$ sehingga data hasil post-test kelompok eksperimen berdistribusi normal. Hasil post-test $\chi^{2}$ hitung kontrol adalah 1,27 dan $\chi^{2}$ tabel dengan taraf signifikansi $5 \%$ dan derajat kebebasan $(\mathrm{dk})=2$ adalah 5,59. Hal ini berarti, $\chi^{2}$ hitung hasil post-test kelompok kontrol lebih kecil dari $\chi^{2}$ tabel $(1,27<5,59)$ sehingga data hasil post-test kelompok kontrol berdistribusi normal. Secara ringkas, hasil uji normalitas sebaran data kelompok eksperimen dan kelompok kontrol disajikan dalam Tabel 2. 
Tabel 2. Hasil Uji Normalitas Sebaran Data

\begin{tabular}{lccc}
\hline Kelompok Data Hasil Belajar & $\chi^{2}$ & $\begin{array}{c}\chi_{\text {tabel dengan Taraf }}^{2} \\
\text { Signifikansi 5\% }\end{array}$ & Status \\
\hline Post-test eksperimen & 3,94 & 5,59 & Normal \\
Post-test kontrol & 1,27 & 5,59 & Normal \\
\hline
\end{tabular}

Selanjutnya dilakukan uji prasyarat yang kedua yaitu uji homogenitas varians. Uji homogenitas varians dilakukan untuk menentukan bahwa kelompok eksperimen dan kelompok kontrol yang sudah ditetapkan tersebut memiliki penguasaan yang sama atau homogen. Uji yang digunakan adalah uji-F dengan kriteria jika $F_{\text {hitung }}<$ $F_{\text {tabel }}$, maka $\mathrm{H}_{0}$ diterima dan varians homogen, jika $F_{\text {hitung }}>F_{\text {tabel }}$, maka $\mathrm{H}_{0}$ ditolak dan varians tidak homogen. Hasil uji F, diperoleh nilai $F_{\text {hitung }}$ hasil post-test kelompok eksperimen dan kelompok kontrol adalah 1,60. $F_{\text {tabel }}$ dengan db pembilang $=19-1=18$ dan db penyebut $=22-1=21$ pada taraf signifikansi $5 \%$ adalah 2,10 . Hal ini berarti bahwa $\mathrm{F}_{\text {hitung }}<\mathrm{F}_{\text {tabel }}(1,60<2,10)$ sehingga data hasil hasil post-test kelompok eksperimen dan kelompok kontrol bersifat homogen.

Hasil uji normalitas sebaran data dan uji homogenitas varians diperoleh hasil post-test kelompok eksperimen dan kelompok kontrol adalah normal dan homogen. Setelah diperoleh hasil dari uji normalitas sebaran data dan uji homogenitas varians, dilanjutkan dengan pengujian hipotesis penelitian $\left(\mathrm{H}_{1}\right)$ dan hipotesis nol $\left(\mathrm{H}_{0}\right)$. Pengujian hipotesis tersebut dilakukan dengan menggunakan uji-t dengan rumus polled varians dengan kriteria $\mathrm{H}_{0}$ ditolak jika $\mathrm{t}_{\text {hitung }}>\mathrm{t}_{\text {tabel }}$ dan $\mathrm{H}_{0}$ diterima jika $\mathrm{t}_{\text {hitung }}<\mathrm{t}_{\text {tabel }}$. Adapun hasil analisis uji-t disajikan dalam Tabel 3.

Tabel 3. Hasil Uji Hipotesis

\begin{tabular}{lccccccc}
\hline $\begin{array}{l}\text { Kelompok } \\
\text { Data Hasil } \\
\text { Belajar IPA }\end{array}$ & Mean & $\begin{array}{c}\text { Varians } \\
\left(s^{2}\right)\end{array}$ & $\mathrm{N}$ & $\begin{array}{c}\mathrm{db} \\
\left(\mathrm{n}_{1}+\mathrm{n}_{2^{-}}\right. \\
2)\end{array}$ & $\mathrm{t}_{\text {hitung }}$ & $\begin{array}{c}\mathrm{t}_{\text {tabel }} \text { dengan taraf } \\
\text { signifikansi 5\% }\end{array}$ & Kesimpulan \\
\hline $\begin{array}{l}\text { Kelompok } \\
\begin{array}{l}\text { Eksperimen } \\
\text { Kelompok }\end{array}\end{array}$ & 24,11 & 16,54 & 19 & & & & \\
Kontrol & 17,23 & 10,28 & 22 & 39 & 6,08 & 2,021 & $\begin{array}{c}\mathrm{t}_{\text {hitung }}>\mathrm{t}_{\text {tabel }} \\
\left(\mathrm{H}_{0} \text { ditolak }\right)\end{array}$ \\
\hline
\end{tabular}

Hasil uji hipotesis diperoleh, $\mathrm{t}_{\text {hitung }}$ sebesar $6,08, \mathrm{t}_{\text {tabel }} \mathrm{db}=\mathrm{n}_{1}+\mathrm{n}_{2}-2=19+22-2=39$ dan taraf signifikansi $5 \%$ adalah 2,021. Hal ini berarti, $\mathrm{t}_{\text {hitung }}$ lebih besar dari $\mathrm{t}_{\text {tabel }}(6,08>2,021)$, sehingga $\mathrm{H}_{0}$ ditolak dan $\mathrm{H}_{1}$ diterima. Dengan demikian, dapat dinyatakan bahwa terdapat pengaruh yang signifikan hasil belajar IPA antara kelompok siswa yang dibelajarkan dengan model pembelajaran kooperatif tipe two stay two stray dan kelompok siswa yang dibelajarkan dengan model pembelajaran konvensional pada siswa kelas V SD Semester II di Gugus IV Kecamatan Abang Kabupaten Karangasem Tahun Pelajaran 2017/2018.

Secara umum, hasil analisis data hasil belajar IPA menunjukan terdapat perbedaan hasil belajar antara kelompok siswa yang dibelajarkan dengan model pembelajaran kooperatif tipe two stay two stray dengan kelompok siswa yang dibelajarkan dengan model pembelajaran konvensional. Kelompok siswa yang dibelajarakan dengan model pembelajaran kooperatif tipe two stay two stray memiliki skor rata-rata lebih tinggi dibandingkan dengan kelompok siswa yang dibelajarkan dengan model pembelajaran konvensional. Tinjauan ini didasarkan pada hasil perhitungan uji-t. Rata-rata skor hasil belajar siswa kelompok eksperimen yang dibelajarkan dengan model pembelajaran kooperatif tipe two stay two stray adalah 24,11 berada pada kategori sangat tinggi, sedangkan rata-rata skor hasil belajar siswa kelompok kontrol yang dibelajarkan dengan model pembelajaran konvensional adalah 17,23 berada pada kategori sedang. Berdasarkan hasil analisis data menggunakan uji-t diperoleh $t_{\text {hitung }}=6,08$ dan $t_{\text {tabel }}=2,021$ untuk $\mathrm{db}=39$ dengan taraf signifikan $5 \%$. Hasil perhitungan tersebut menunjukkan bahwa $t_{\text {hitung }}>t_{\text {tabel }}$, sehingga $\mathrm{H}_{0}$ ditolak dan $\mathrm{H}_{1}$ diterima.

Perbedaan hasil belajar antara kelompok siswa yang dibelajarkan dengan model pembelajaran kooperatf tipe two stay two stray dengan kelompok siswa yang dibelajarkan dengan model pembelajaran konvensional, disebabkan oleh adanya perbedaan perlakuan pada langkah-langkah pembelajaran dan proses pembelajaran dikelas. 
Siswa kelas V SD Negeri 2 Culik yang merupakan kelompok eksperimen, diberikan perlakuan dengan dibelajarakan menggunakan model pembelajaran kooperatif tipe two stay two stray. Dalam model pembelajaran ini peran guru sebagai fasilitator dan motivator dalam pembelajaran, sementara semua siswa aktif melakukan proses pembelajaran mulai dari menemukan solusi permasalahan, diskusi, dan berbagi pengalaman. Model pembelajaran ini memberikan kesempatan kepada setiap kelompok untuk saling bertukar pikiran dan berbagi informasi dengan cara bertamu ke kelompok lain sehingga terjadi satu pendapat yang sama dengan semua kelompok setelah didiskusikan bersama. Temuan ini sesuai dengan pendapat yang dikemukakan oleh Karlina (2017) yang menyatakan bahwa model pembelajaran kooperatif tipe two stay two stray tidak berpusat pada guru melainkan pada siswa sehingga siswa sendiri yang aktif menggali pengetahuannya dan bertanggung jawab untuk memperoleh sendiri pengetahuannya yang diperlukan melalui interaksi dengan anggota kelompoknya.

Model pembelajaran kooperatif tipe two stay two stray lebih menekankan pada aktivitas siswa melalui sintaks/langkah-langkah sebagai berikut: 1) tahap pembagian kelompok oleh guru, yang mana kelompok tersebut merupakan kelompok heterogen yang terdiri dari 4 orang; 2) tahap pemberian tugas, yang harus didiskusikan oleh setiap kelompok; 3) tahap pembagian 2 orang menjadi tamu dan 2 orang tinggal dalam kelompok; 4) tahap pembahasan, siswa bersama guru membahas dan mencocokkan informasi yang diperoleh; 5) tahap pemberian penghargaan dan hukuman, siswa yang dapat membahas dan mencocokkan informasi yang diperoleh mendapat reward, siswa yang tidak dapat membahas dan mencocokkan informasi yang diperoleh mendapat hukuman (dimodifikasi dari Huda, 2013).

Ditinjau dari proses pembelajaran, aktivitas siswa yang dibelajarkan dengan model pembelajaran kooperatif tipe two stay two stray lebih aktif dalam pembelajaran. Siswa lebih aktif, karena siswa harus bertamu ke kelompok lain untuk mencari informasi dan bagi siswa yang diam dalam kelompok harus membagi informasi kepada kelompok lain yang bertamu. Dengan kegiatan bertamu, akan terbentuk interaksi dan komunikasi positif antar siswa. Kegiatan bertamu juga menjadikan siswa dalam masing-masing kelompok mendapat tanggung jawab untuk menyelesaikan tugas bertamu dan menerima tamu dengan baik sehingga akan dituntut pertanggung jawaban individu yang mengakibatkan siswa tidak akan melalaikan dan mengabaikan tugasnya dalam bertamu dan menerima tamu. Temuan ini sesuai dengan pendapat yang dikemukakan oleh Dewi (2017) yang menyatakan bahwa, melalui kegiatan bertamu atau berkunjung ke kelompok lain siswa akan memperoleh informasi yang lebih lengkap dari sekedar yang diketahui dan secara tidak langsung siswa akan aktif berdiskusi, tanya jawab, mencari jawaban, menjelaskan dan menyimak materi yang dijelaskan oleh temannya.

Berbeda halnya dengan model pembelajaran konvensional, guru hanya memberikan teori-teori maupun materi pelajaran secara langsung kepada siswa melalui kegiatan ceramah, tanya jawab, siswa mencatat poin-poin penting dari materi yang dijelaskan oleh guru dan memberikan tugas untuk menjawab pertanyaan yang ada dibuku. Siswa tidak mendapat kesempatan menemukan pengetahuannya sendiri melalui proses-proses tertentu, dengan kata lain guru yang mendominasi dalam pembelajaran dikelas (teacher centered). Sedangkan siswa hanya sebagai pendengar dan penerima informasi secara pasif. Hal tersebut sesuai dengan penjelasan Rasana (2009) yang menyatakan bahwa penyampaian materi dalam pembelajaran konvensional lebih banyak dilakukan melalui ceramah, tanya jawab, dan penugasan yang berlangsung secara terus-menerus. Di dalam proses pembelajaran siswa jarang mendapatkan kesempatan untuk berinteraksi dengan siswa lainnya. Kondisi ini cenderung membuat siswa tidak termotivasi, bosan dan kurang bergairah dalam mengikuti pembelajaran sehingga hasil belajar yang diperoleh cenderung rendah.

Apabila ditinjau secara operasional, hasil belajar siswa yang menggunakan model pembelajaran kooperatif tipe two stay two stray lebih baik dibandingkan hasil belajar siswa yang memperoleh pembelajaran konvensional. Melalui perbedaan tersebut, maka penggunaan model pembelajaran kooperatif tipe two stay two stray dalam proses pembelajaran dapat dikatakan memberikan pengaruh yang lebih baik dibandingkan dengan pembelajaran konvensional.

Hasil penelitian ini sejalan dengan hasil dari beberapa penelitian tentang model pembelajaran kooperatif tipe two stay two stray yang dilakukan oleh Antari (2017) dengan hasil penelitian yang menyatakan bahwa terdapat pengaruh yang model pembelajaran kooperatif tipe two stay two stray (TSTS) terhadap kompetensi pengetahuan IPS siswa kelas V SD Gugus Letda Made Putra. Paramita (2016) dengan hasil penelitian tersebut menunjukkan bahwa model pembelajaran kooperatif two stay two stray berbantuan peta konsep berpengaruh terhadap hasil belajar IPS siswa kelas V SD di Gugus I Kecamatan Gianyar Tahun 2015/2016. Kusumadewi (2017) dengan hasil penelitian yang menyatakan bahwa terdapat pengaruh model pembelajaran two stay two stray berbantuan media audio visual terhadap kompetensi pengetahuan IPS siswa kelas V SD Gugus Kompyang Sujana Kecamatan Denpasar Utara.

Pratiwi (2016) dengan hasil penelitian yang menunjukkan bahwa model pembelajaran kooperatif tipe two stay two stray berpengaruh terhadap hasil belajar IPA siswa kelas V SD di Gugus 3 Udayana Kecamatan Mendoyo, Kabupaten Jembrana. Diarsa (2017) dengan penelitian yang menyatakan terdapat pengaruh model pembelajaran two stay two stray berbantuan media visual terhadap hasil belajar IPA siswa kelas V SD di Gugus V Kecamatan Bangli Tahun Pelajaran 2015/2016. Serta penelitian yang dilakukan oleh Dewi (2017) yang 
menyatakan terdapat pengaruh model pembelajaran two stay two stray berbantuan media audio visual terhadap kompetensi pengetahuan IPA pada siswa kelas V SD di Gugus Letda Made Putra Tahun Pelajaran 2015/2016.

\section{Simpulan dan Saran}

Berdasarkan analisis data dan pengujian hipotesis yang telah dilakukan dapat disimpulkan bahwa pengaruh yang signifikan hasil belajar IPA antara kelompok siswa yang dibelajarkan model pembelajaran kooperatif tipe two stay two stray dengan kelompok siswa yang dibelajarkan model pembelajaran konvensional pada siswa kelas V SD Semester II di Gugus IV Kecamatan Abang Kabupaten Karangasem Tahun Pelajaran 2017/2018. Hal ini dapat dilihat dari hasil uji-t kedua kelas penelitian pada taraf siginifikasi 5\% dan derajat kebebasan $(\mathrm{dk})=39$, yang meunjukkan $\mathrm{t}_{\text {hitung }}>\mathrm{t}_{\text {tabel }}$, dengan nilai $\mathrm{t}_{\text {hitung }}=6,08$ dan $\mathrm{t}_{\text {tabel }}=2,021$ sehingga $\mathrm{H}_{0}$ ditolak dan $\mathrm{H}_{1}$ diterima. Rata-rata kelompok eksperimen sebsar 24,11 dan rata-rata kelompok kontrol sebesar 17,23. Hal ini berarti rata-rata kelompok eksperimen lebih besar dari pada rata-rata kelompok kontrol. Adanya perbedaan tersebut menunjukan bahwa model pembelajaran kooperatif tipe two stay two stray berpengaruh positif terhadap hasil belajar IPA siswa kelas V SD Semester II di Gugus IV Kecamatan Abang Kabupaten Karangasem Tahun Pelajaran 2017/2018

Berdasarkan temuan-temuan dalam penelitian ini, adapun beberapa saran yang ingin disampaikan sebagai berikut. Disarankan kepada siswa agar selalu memotivasi diri untuk belajar sehingga hasil belajar yang maksimal mampu dicapai. Selain itu, disarankan kepada siswa agar selalu menjaga kedisiplinan dalam kelas. Disarankan kepada guru di SD agar selalu mencoba melakukan inovasi dalam pembelajaran khususnya mata pelajaran IPA seperti menggunakan model-model pembelajaran inovatif, salah satunya model pembelajaran kooperatif tipe two stay two stray sehingga dapat memberikan pengaruh positif terhadap hasil belajar IPA siswa.

Disarankan kepada kepala sekolah agar selalu mendukung penerapan model-model pembelajaran inovatif dalam pembelajaran di SD salah satunya model pembelajaran kooperatif tipe two stay two stray sehingga nantinya dapat meningkatkan hasil belajar siswa. Disarankan kepada peneliti lain yang berminat untuk mengadakan penelitian tentang model pembelajaran kooperatif tipe two stay two stray dalam mata pelajaran IPA maupun mata pelajaran lainnya yang sesuai, hendaknya memperhatikan kendala-kendala yang dialami dalam penelitian ini sehingga mendapatkan hasil penelitian yang lebih sempurna.

\section{Daftar Pustaka}

Antari, Ni Luh Putu Yuni. 2017. "Pengaruh Model Pembelajaran Kooperatif Tipe Two Stay Two Stray (TSTS) Berbantuan Multimedia Terhadap Kompetensi Pengetahuan IPS Siswa Kelas V SD Gugus Letda Made Putra". E-Journal Mimbar PGSD Universitas Pendidikan Ganesha, Volume 5, Nomor 2 (hlm. 1-10).

Darmayasa, I.W.G.S. 2013. "Penerapan Model Pembelajaran Kooperatif Tipe Two Stay Two Stray Berbantuan Media Gambar Untuk Meningkatkan Motivasi Dan Hasil Belajar PKn”. E-Journal Mimbar PGSD Universitas Pendidikan Ganesha, Volume 1 (hlm. 1-10).

Dewi, Ni Nyoman Rustia. 2017. "Pengaruh Model Pembelajaran Kooperatif Tipe Two Stay Two Stray Berbantuan Media Audio Visual terhadap Kompetensi Pengetahuan IPA Siswa Kelas V SD Gugus Letda Made Putra". E-Journal Mimbar PGSD Universitas Pendidikan Ganesha, Volume 5, Nomor 2 (hlm. 110).

Diarsa, I P. 2017. "Pengaruh Model Pembelajaran Two Stay Two Stray Berbantuan Media Visual Terhadap Hasil Belajar IPA Siswa". E-Journal Mimbar PGSD Universitas Pendidikan Ganesha, Volume 5, Nomor 2 (hlm. 1-11).

Huda, Miftahul. 2013. Model-Model Pengajaran dan Pembelajaran Isu-Isu Metodis dan Paradigmatis. Yogyakarta: Pustaka Pelajar.

Karlina, Cici Fitrayatun . 2017. "Pembelajaran Kooperatif Tipe (TSTS) Berbantuan Peta Pikiran Untuk Meningkatkan Hasil Belajar IPA Melalui Lesson Study”. E-Journal Mimbar PGSD Universitas Pendidikan Ganesha, Volume 5, Nomor 2, (hal-1-12)

Koyan, I Wayan. 2011. Asessmen dalam Pendidikan. Singaraja: Universitas Pendidikan Ganesha Press.

Kusumadewi, Made Ayu. 2017. "Pengaruh Model Pembelajaran Two Stay Two Stray Berbantuan Media Audio Visual Terhadap Kompetensi Pengetahuan IPS Siswa Kelas V SD Gugus Kompyang Sujana Kecamatan Denpasar Utara". E-Journal Mimbar PGSD Universitas Pendidikan Ganesha, Volume 5, Nomor 2 (hlm. 1-10).

Lie. 2002. Mempraktikkan Cooperative Learning di Ruang-ruang Kelas. Jakarta: Gramedia.

Paramita, Ni Luh Putu Intan. 2016 "Pengaruh Model Pembelajaran Two Stay Two Stray Berbantuan Peta Konsep Terhadap Hasil Belajar IPS Siswa Kelas V SD Gugus I Kecamatan Gianyar Tahun 2015/2016”. E-Journal Mimbar PGSD Universitas Pendidikan Ganesha, Volume 4, Nomor 1 (hlm. 1-10).

Pratiwi, Ni Kadek Chandra. 2016. "Pengaruh Model Kooperatif Two Stay Two Stray Terhadap Hasil Belajar IPA" ". E-Journal Mimbar PGSD Universitas Pendidikan Ganesha, Volume 4, Nomor 1 (hlm. 1-12). 
Putri, Ni Kadek Yuni Retna. 2017. "Pengaruh Model Pembelajaran Cooperative Learning Type TSTS Terhadap Kompetensi Pengetahuan IPA Siswa Kelas V". E-Journal Mimbar PGSD Universitas Pendidikan Ganesha, Volume 5, Nomor 2 (hlm. 1-11).

Rasana, Raka. 2009. Model-model Pembelajaran. Singaraja: Universitas Pendidikan Ganesha.

Sugiyono. 2011a. Metode Penelitian Kuantitatif, Kualitatif dan R \& D. Bandung: Alfabeta.

Susanto, Ahmad. 2013. Teori Belajar \& Pembelajaran di Sekolah Dasar. Jakarta: Kencana. 